\title{
NEKATERI REZULTATI KLIMATSKIH MERITEV V PLANICI S POUDARKOM NA MERITVAH TERMINALNIH POGANJKOV DREVES
}

\author{
Darko Ogrin*, Marko Krevs**
}

Izvleček

UDK $911 \cdot 2: 551.584$ (497.12 Planica)

$V$ prispevku so analizirane klimatske razmere v planiški dolini z vidika sončnega obsevanja, temperaturnih razmer in lokalne zračne cirkulacije. Poseben poudarek, tudi metodološki, je namenjen raziskavi odnosa med višinskim priraščanjem bukve, macesna, rušja in smreke ter klimatskimi in ostalimi rastiščnimi pogoji.

Ključne besede: klimatogeografija, lokalna klimatogeografija, mikroklimatogeografija, višinska prirast dreves, Julijske Alpe

\section{SOME RESULTS OF CLIMATIC MEASUREMENTS PERFORMED IN PLANICA, WITH THE EMPHASIS ON THE MEASUREMENTS OF TERMINAL INCREMENTS OF TREES}

Abstract

UDC $911 \cdot 2: 551.584$ (497.12 Planica)

Climatic conditions in the valley of Planica are analysed from the aspect of insolation, temperature conditions, and local air circulation. A special emphasis, the methodological one as well, is laid on the investigation of the relation between the vertical terminal increments of beech, laryx, Pinus mugo and spruce, and the climatic, as well as other growth conditions.

Key words: climatogeography, local climatogeography, microclimatogeography, vertical increment of trees, Julian Alps

\section{UVOD}

Toplotne razmere $\mathrm{v}$ alpskih dolinah so $\mathrm{v}$ glavnem posledica nadmorske višine in razlik $v$ sončnem obsevanju. Različna obsijanost s soncem je zelo pomembna tudi za razvoj lokalne zračne cirkulacije. V primeru Planice so nas zanimale toplotne razlike v vzdolžnem profilu, ki so večinoma posledica nadmorske višine in razlike v prečnem profilu, kjer se spremembam zaradi višine pridruži še različna obsijanost s soncem.

Izračunani temperaturni gradienti, ki pa jih ne moremo posplošiti na raven povprečnih vrednosti in nekatere vegetacijske posebnosti so pokazale, da so mikroklimatske raz-

\footnotetext{
** Mag., asistent, Oddelek za geografijo, Filozofska fakulteta Univerze $v$ Ljubljani, Aškerčeva 2, 61000 Ljubljana, Slovenija
} 
like med posameznimi deli doline znatne. Da bi dobili boljšo predstavo o klimatskih razmerah doline, predvsem pa o vplivu le-teh na terminalne prirastke dreves, smo njihove prvotne testne meritve zgostili, tako da smo profilno pokrili celotno dolino. Ker višinska prirast pri drevesih ni odvisna samo od klimatskih razmer, ampak tudi od ostalih dejavnikov $v$ okolju, smo poseben poudarek dali tudi metodološki plati raziskave.

V strokovni literaturi so klimatske razmere gorskih dolin in gorskega sveta na splošno dobro raziskane. $\mathrm{V}$ ospredju zanimanja je tematika, povezana s sončnim obsevanjem, temperaturnimi in padavinskimi razmerami, ter lokalno zračno cirkulacijo (F. Lehmkuhl et al., 1992; M. Winiger et al., 1992; M. M. Bachmann, 1993; P. Seibert, 1993; K.F. Wetzel, 1994; idr.).

Pogoste so tudi fitogeografske in splošno ekološke študije, ki obravnavajo rastne pogoje v gorskem svetu (P. Plesnik, 1971; F. Lovrenčak, 1976; 1978; 1983; 1986 in 1987; I. Gams at al., 1978; I. Gams, 1987; B. Bacceti, 1989).

Na podlagi drobnih raziskav so nastala tudi posamezna pregledna dela, ki kompleksno obravnavajo klimatsko problematiko gorskega sveta (R. Geiger,1966; R.G.Barry, 1981).

Gradivo, ki je obdelano v prispevku, je rezultat terenskega dela študentov 2. letnika geografije Filozofske fakultete Univerze v Ljubljani v šolskih letih 1987/88 do 1992/93. Pri meritvah terminalnih poganjkov leta 1994 sta sodelovali tudi Valentina Brečko in Zdenka Šimonovič. Vsem skupaj se za pomoč najlepše zahvaljujemo.

\section{OBMOČJE RAZISKOVANJA}

Raziskava je potekala $v$ dolini Planica, $v$ severozahodnem delu Slovenije, ob slovensko-italijanski meji. Planiška dolina, ki se pri Ratečah izteka v glavno dolino Save Dolinke, ima prevladujočo smer sever-jug, le skrajni južni konec doline poteka $v$ smeri severovzhod-jugozahod. Dno doline leži v nadmorski višini med $850 \mathrm{~m}$ pri Ratečah in $1250 \mathrm{~m}$ na prehodu južnega konca doline $\mathrm{v}$ melišča, ki se spuščajo izpod Jalovca, Kotovega sedla in Šit (slika 1).

Dolina je ledeniško preoblikovana s prečnim profilom $v$ obliki črke $U$ in večinoma zasuta $\mathrm{z}$ morenskim gradivom, ki ga prerašč gozd. Morensko gradivo tvori ponekod po sredi doline izrazit hrbet, ki se znižuje proti robovom doline (V. Bohinec, 1935; A. Melik, 1961; I. Gams, 1992). Bočne dele doline zasipavajo na zahodni strani večinoma podstenska, na vzhodni strani pa podžlebna melišča. Vzrok za to je po I. Gamsu (1992) v različni litološki sestavi doline in z njo povezanimi reliefnimi razmerami. Strmine pobočij nad dolino so različne, prevladujejo nakloni nad 33 stopinj. 


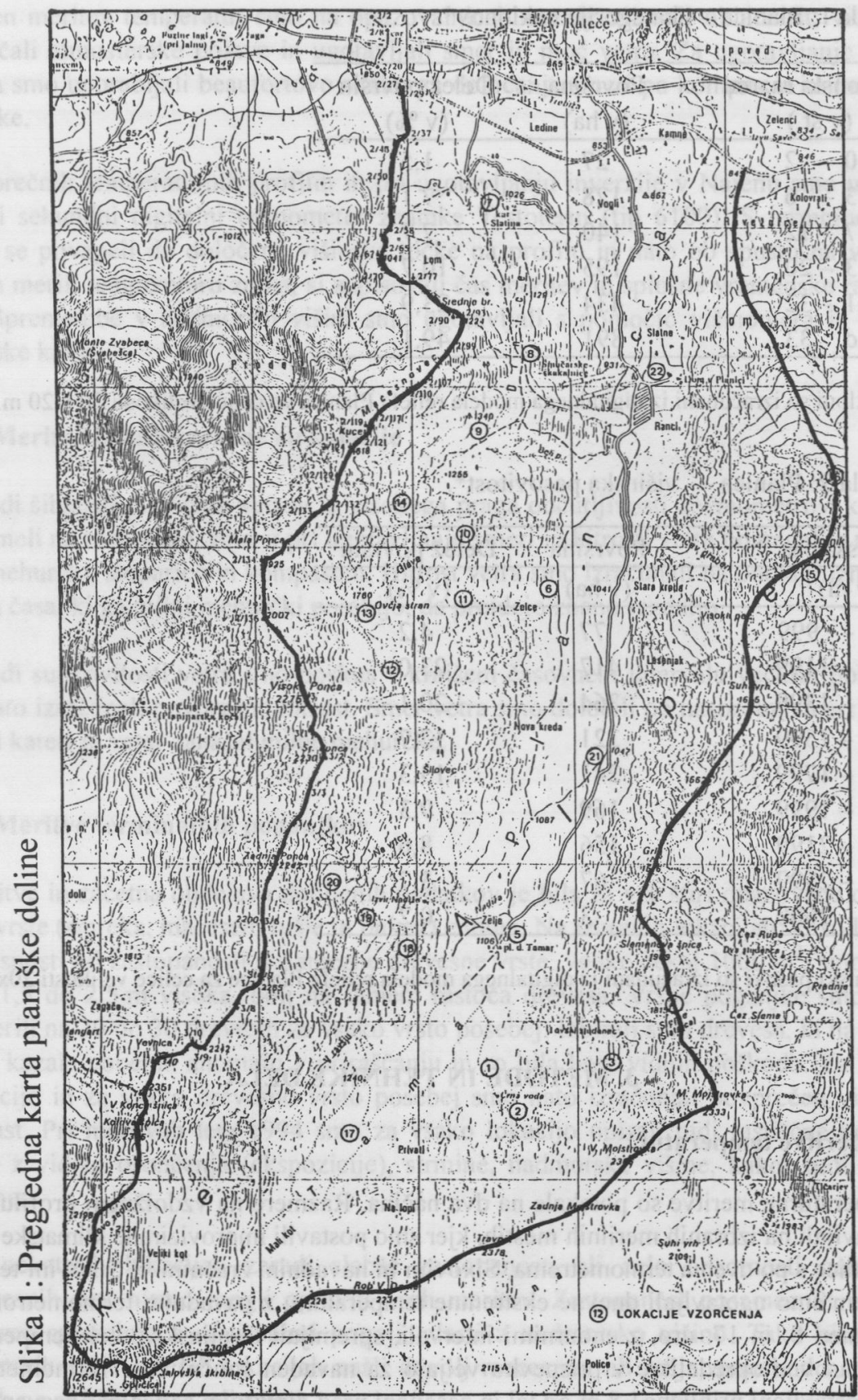


Tabela 1: Planica - kategorije naklonov*.

\begin{tabular}{ccc}
\hline $\begin{array}{c}\text { Naklonski razred } \\
(\mathrm{v} \text { st. })\end{array}$ & $\begin{array}{c}\text { Površina } \\
(\mathrm{v} \text { ha })\end{array}$ & $\begin{array}{c}\text { Delež površin } \\
(\mathrm{v} \%)\end{array}$ \\
\hline $0-2$ & 27 & 1,5 \\
$3-6$ & 128 & 7,1 \\
$7-12$ & 140 & 7,7 \\
$13-20$ & 195 & 10,7 \\
$21-32$ & 434 & 23,9 \\
nad 33 & 891 & 49,1 \\
\hline
\end{tabular}

* Nakloni so izračunani iz digitalnega modela reliefa Planice za celice velikosti $20 \times 20 \mathrm{~m}$.

Tabela 2: Planica - višinska pasovitost*.

\begin{tabular}{ccc}
\hline Višinski pas & Površina & Delež površin \\
\hline \multicolumn{1}{c}{$(\mathrm{v} \mathrm{m})$} & $(\mathrm{v}$ ha $)$ & $(\mathrm{v} \%)$ \\
\hline $800-999$ & 77 & 4,2 \\
$1000-1199$ & 417 & 23,0 \\
$1200-1399$ & 364 & 20,1 \\
$1400-1599$ & 321 & 17,7 \\
$1600-1799$ & 241 & 13,3 \\
$1800-1999$ & 169 & 9,3 \\
$2000-2199$ & 156 & 8,6 \\
$2200-2399$ & 67 & 3,7 \\
$2400-2600$ & 3 & 0,2 \\
\hline
\end{tabular}

*Višinski pasovi so izračunani iz digitalnega modela reliefa Planice za celice velikosti $20 \times 20 \mathrm{~m}$

\section{METODE IN TEHNIKE DELA}

\subsection{Meritve temperatur}

Temperaturne meritve so potekale na dva načina. Razmere na vzdolžnem profilu smo ugotavljali na izbranih merilnih mestih, kjer smo postavili improvizirane klimatske opazovalnice s po dvema termometroma, Sixovim in navadnim zračnim. S Sixovim termometrom smo ugotavljali dnevne ekstremne temperature, $\mathrm{z}$ navadnim termometrom pa smo med 8. in 17. uro, $\mathrm{z}$ enournimi intervali, spremljali terminski potek temperatur. Vse časovne opredelitve $\mathrm{v}$ prispevku veljajo za navaden sončni čas. Termometri so bili postavljeni približnol,8 m od tal in zaščiteni pred direktnim sončnim obsevanjem. 
Razen meritev temperatur smo na opazovalnicah ocenjevali tudi oblačnost, vidnost, določali atmosferske pojave in ugotavljali smer in moč vetra. Za ugotavljanje moči vetra smo uporabljali beaufortovo skalo, za določanje smeri pa kompas in milne mehurčke.

Pri prečnih temperaturnih profilih in pri ugotavljanju inverzije $v$ Najenu smo uporabljali sekundni digitalni termometer znamke Testoterm (tip 6100). S termometrom smo se povzpeli do določene višinske točke na profilu in nato ob spustu na vsakih $50 \mathrm{~m}$ merili temperaturo zraka, si zapisovali čas meritev in splošne vremenske razmere. Spremembe v nadmorski višini smo ugotavljali s pomočjo višinomera in topografske karte.

\subsection{Meritve lokalne zračne cirkulacije}

Zaradi šibkosti pobočnih vetrov in visokega praga občutljivosti anemometrov, ki smo jih imeli na razpolago, smo si pri ugotavljanju smeri in hitrosti vetra pomagali z milnimi mehurčki, štoparico in kompasom. Hitrost vetra smo izračunali na podlagi izmerjenega časa, ki ga milni mehurčki porabijo, da preidejo znano razdaljo.

Zaradi sunkovitosti vetra smo poskus $v$ krajšem časovnem intervalu večkrat ponovili in nato izračunali povprečno hitrost. Smer vetra smo določili po nasprotni smeri neba, proti kateri je veter zanašal milne mehurčke.

\subsection{Meritve terminalnih poganjkov}

Meritve in začetna obdelava dobljenih podatkov je bila za vse štiri opazovane drevesne vrste (smreka, macesen, rušje in bukev) enotna. Na izbranih lokacijah, ki so bile, $v$ odvisnosti od zastopanosti posamezne drevesne vrste, velike nekaj $1000 \mathrm{~m}^{2}$, smo izbirali 1,5 do $2,5 \mathrm{~m}$ visoka, bolj na samem rastoča drevesa. Vršne poganjke smo nato izmerili na 20 do 30 drevesih za vsako vrsto posebej. Izbirali smo drevesa, ki na zunaj niso kazala nobenih anomalij v priraščanju in so bila brez vidnih poškodb. Za vsako lokacijo in za vsako drevesno vrsto posebej smo nato izračunali povprečen višinski prirast. Pri meritvah leta 1994 smo za vsako lokacijo opisali tudi rastiščne pogoje, tako $\mathrm{z}$ vidika osončenja (ekspozicije), strmine, nadmorske višine, kakor tudi talnih razmer.

$\mathrm{Na}$ nekaterih lokacijah zaradi slabše zastopanosti ali celo odsotnosti nekaterih drevesnih vrst nismo mogli opraviti vseh meritev. Zastopanost posameznih vrst se namreč spreminja $\mathrm{z}$ rastiščnimi pogoji, zlasti $\mathrm{z}$ nadmorsko višino. Tako nismo na nekaterih nižje ležečih lokacijah našli dovolj macesnov ali rušja, ponekod na višjih legah pa ni bilo bukev ali smrek. 


\section{REZULTATI}

\subsection{Sončno obsevanje}

Podatki o sončnem obsevanju za Rateče, ki ležijo ob izteku planiške doline v dolino Save Dolinke, so zbrani vtabeli 3 . Iz podatkov je razvidno, da sonce v Ratečah v povprečju najdlje sije v obeh osrednjih poletnih mesecih, nekaj nad 7 ur dnevno, najmanj pa decembra in januarja, 2 do 3 ure na dan. Poudariti pa velja, da so navedeni podatki preračunani na matematični horizont in da odražajo samo astronomske in meteorološke razmere, odstranjen pa je vpliv reliefa (Klimatografija Slovenije, tretji zvezek, 1991). Zaradi vpliva reliefa so dejanske vrednosti nižje, še zlasti v srednjem in zgornjem delu planiške doline, ki je obdana z visokimi gorskimi grebeni.

Tabela 3: Nekateri podatki o sončnem obsevanju za postajo Rateče-Planica (n.v. 864 m). Povprečki so za obdobje 1961-90.

$\begin{array}{lrrrrrrrrrrrrr} & \text { JAN. } & \text { FEB. } & \text { MAR. } & \text { APR. } & \text { MAJ } & \text { JUN. } & \text { JUL. } & \text { AVG. } & \text { SEP. } & \text { OKT. } & \text { NOV. } & \text { DEC. } & \text { LETO } \\ \text { Dnev. št. ur s soncem } & 2,8 & 4,1 & 4,7 & 5,2 & 5,8 & 6,5 & 7,4 & 7,2 & 6,4 & 4,6 & 3,2 & 1,8 & 5,0 \\ \text { Pov. oblač. (desetine) } & 5,7 & 5,6 & 6,1 & 6,4 & 6,2 & 6,2 & 5,3 & 5,1 & 5,2 & 5,4 & 6,2 & 5,7 & 5,8 \\ \text { Štev. jasnih dni } & 5,7 & 6,3 & 4,3 & 3,2 & 2,4 & 2,2 & 4,6 & 5,2 & 5,7 & 6,3 & 4,6 & 5,7 & 56,3 \\ \text { Śtev. oblačnih dni } & 10,2 & 9,4 & 11,2 & 10,6 & 9,2 & 8,8 & 5,6 & 6,0 & 7,0 & 9,3 & 11,7 & 10,4 & 109,3\end{array}$

Vir: Arhiv HMZ Slovenije.

Glede na teoretično izračunano pot sonca in potek horizonta se sonce pri planinskem domu Tamar (n.v. 1106 m) v zgornjem delu planiške doline okoli zimskega solsticija sploh ne dvigne nad horizont. V dneh okoli enakonočja sije, če ne upoštevamo meteoroloških razmer, okoli 3 ure dnevno, v času poletnega obrata pa nekaj nad 9 ur dnevno.

Teoretično obsijanost celotne planiške doline s soncem ob poletnem obratu prikazujejo slike 2 a, b in c. Ob 7. uri zjutraj (slika 2a) je s soncem obsijan spodnji in zahodni del doline (gorski greben med Macesnovcem in Jalovcem), v senci pa je vzhodno pobočje med Ciprnikom in Šitami. Ob zgornji kulminaciji sonca (slika 2b) je, razen posameznih manjših predelov pod ostenjem Travnika in Šit, celotna dolina v soncu. Ob 17. uri (slika 2c), ko sonce počasi že zahaja za greben med Poncami in Jalovcem, pa je razen Kotovega sedla in desnega pobočja hudournika izpod Macesnovca, celotno zahodno pobočje in dolinsko dno v senci, s soncem pa je obsijan spodnji del doline in vzhodno pobočje. 
Za razmere ob enakonočju ob zgornji kulminaciji sonca je značilno, da je večina doline obsijana (slika 2d). Večje sklenjeno območje brez direktnega sončnega obsevanja je le pod grebenom med Malo Mojstrovko in Šitami. Osončenost doline je bila izračunana z računalniškim programom Sonček (M. Gabrovec, M. Krevs, 1988-1991).

Slika 2: Primeri osončenosti doline Planica ob jasnem vremenu.

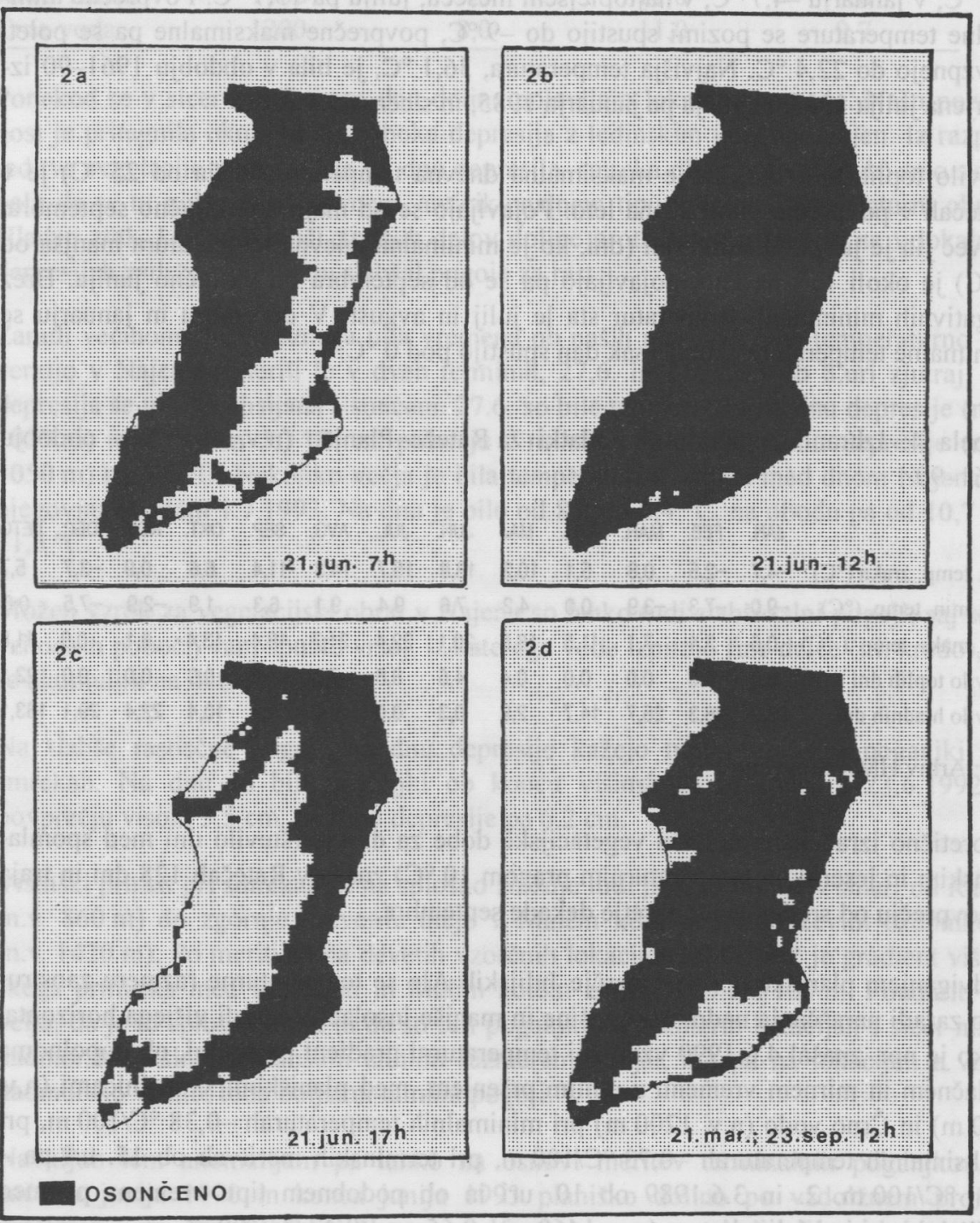




\subsection{Profilne meritve temperatur $v$ povezavi $z$ višinskim prirastkom smreke in macesna}

\subsubsection{Vzdolžni profil doline}

Po podatkih za Rateče je povprečna letna temperatura $v$ spodnjem delu Planice $5,7^{\circ} \mathrm{C}$, v januarju $-4,7^{\circ} \mathrm{C}$, v najtoplejšem mesecu, juliju pa $15,7^{\circ} \mathrm{C}$. Povprečne minimalne temperature se pozimi spustijo do $-9{ }^{\circ} \mathrm{C}$, povprečne maksimalne pa se poleti povzpnejo do $22,4{ }^{\circ} \mathrm{C}$. Najvišja temperatura, $36,1^{\circ} \mathrm{C}$, je bila v obdobju $1961-90$ izmerjena julija 1983 , najnižja pa januarja 1985 , in sicer $-26,4{ }^{\circ} \mathrm{C}$.

Število toplih dni (dni, ko je maksimalna dnevna temperatura višja od $25^{\circ} \mathrm{C}$ ) je v Ratečah v povprečju okoli 22 na leto. Pojavljajo se od maja do vključno septembra, največ jih je julija. Hladnih dni (dni, ko je minimalna dnevna temperatura manjša od $0{ }^{\circ} \mathrm{C}$ ) je okoli 163 na leto, pojavljajo pa se od septembra do vključno junija. Brez negativnih minimalnih temperatur sta le julij in avgust. $\mathrm{V}$ decembru in januarju se minimalne temperature skoraj vsak dan spustijo pod $0{ }^{\circ} \mathrm{C}$.

Tabela 4: Izbrani temperaturni podatki za Rateče-Planico (n.v. $864 \mathrm{~m}$ ) v obdobju 1961-90.

JAN. FEB. MAR. APR. MAJ JUN. JUL. AVG. SEP. OKT. NOV. DEC. LETO

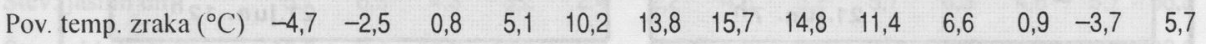

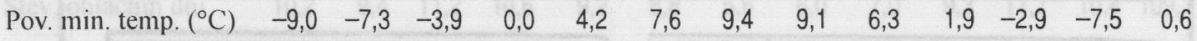

$\begin{array}{llllllllllllll}\text { Pov. maks. temp. }\left({ }^{\circ} \mathrm{C}\right) & 0,6 & 3,4 & 7,1 & 11,5 & 16,5 & 20,1 & 22,4 & 21,7 & 18,4 & 13,4 & 6,1 & 0,9 & 11,8\end{array}$

$\begin{array}{llllllllllllll}\text { Število toplih dni } \quad 0,0 & 0,0 & 0,0 & 0,0 & 0,4 & 4,5 & 8,8 & 7,0 & 1,3 & 0,0 & 0,0 & 0,0 & 22,1\end{array}$

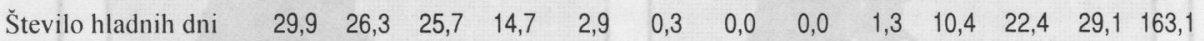

Vir: Arhiv HMZ Slovenije

Teoretično izračunana dolžina vegetacijske dobe za drevje (število dni med spomladanskim in jesenskim temperaturnim pragom $10^{\circ} \mathrm{C}$ ) znaša $\vee$ Ratečah 128 dni in traja $\mathrm{v}$ povprečju od srede maja do tretje dekade septembra.

$\mathrm{Z}$ dviganjem planiške doline $\mathrm{v}$ osrčje Julijskih Alp se temperaturne razmere zaostrujejo zaradi naraščanja nadmorske višine in manjše insolacije zaradi višjega horizonta. Tako je npr. znašal 4.6.1990 vzdolžni temperaturni gradient po dolini, ob popolnoma oblačnem in mirnem vremenu z rahlim pršenjem, med planiškimi skakalnicami (n.v. $940 \mathrm{~m}$ ) in Črno vodo (n.v. $1200 \mathrm{~m}$ ) pri minimalnih temperaturah $-0,38^{\circ} \mathrm{C} / 100 \mathrm{~m}$, pri maksimalnih temperaturah $-0,73{ }^{\circ} \mathrm{C} / 100 \mathrm{~m}$, pri terminskih meritvah ob 15 . uri pa $1,31^{\circ} \mathrm{C} / 100 \mathrm{~m}$. 2. in 3.6.1989 ob 10 . uri in ob podobnem tipu vremena pa med skakalnicami in Malim kotom (n.v. $1460 \mathrm{~m}$ ) $-0,65$ oz. $-0,47^{\circ} \mathrm{C} / 100 \mathrm{~m}$. 
Tabela 5: Temperature na profilu med planiškimi skakalnicami in Črno vodo 4.6.1990.

\begin{tabular}{lcccc}
\hline Merilno mesto & $\begin{array}{c}\text { Nad. viš. } \\
(\mathrm{m})\end{array}$ & $\begin{array}{c}\text { Min. temp. } \\
\left({ }^{\circ} \mathrm{C}\right)\end{array}$ & $\begin{array}{c}\text { Maks. temp. } \\
\left({ }^{\circ} \mathrm{C}\right)\end{array}$ & $\begin{array}{c}\text { Temp. ob } 16^{\mathrm{h}} \\
\left({ }^{\circ} \mathrm{C}\right)\end{array}$ \\
\hline Skakalnice & 940 & 9,0 & 12,9 & 13,1 \\
Najen & 1000 & 9,0 & 11,8 & 11,2 \\
Koča Tamar & 1108 & 9,0 & 12,8 & 10,6 \\
Črna voda & 1200 & 8,0 & 11,0 & 9,7 \\
\hline
\end{tabular}

Ponekod se $v$ sicer razgibanem dnu doline pojavljajo lokalne depresije. Našo pozornost je pritegnila okoli $10 \mathrm{~m}$ globoka depresija z ledinskim imenom Najen. Iz razporeditve vegetacije v njej (rušje po dnu depresije, smreka ob njenih robovih) smo sklepali, da se tu pojavlja ob mirnem, anticiklonalnem tipu vremena temperaturni obrat. Hladen zrak, ki drsi ponoči z višjih delov doline proti Ratečam, naj bi se v lokalnih depresijah zadrževal in s tem slabšal pogoje za rast.

Zaradi večinoma neustreznega tipa vremena ob naših meritvah smo temperaturno inverzijo $v$ Najenu izmerili le $v$ dveh terminih, 27,6. in 1.7.1993 ob 8.uri zjutraj, ko depresija še ni bila obsijana s soncem. 27.6. so bile temperature na dnu depresije (n.v. $1039 \mathrm{~m}$ ) med 5,1 in $5,3{ }^{\circ} \mathrm{C}$, na pobočju $5 \mathrm{~m}$ višje $6,6^{\circ} \mathrm{C}$, na vrhu depresije (n.v. $1050 \mathrm{~m}$ ) pa $7,5^{\circ} \mathrm{C}$. Nekoliko večja je bila temperaturna razlika med dnom Najena in njegovim obodom 1.7.1993. Na dnu je bilo od 8,2 do $8,4^{\circ} \mathrm{C}$, na obodu pa od 10,7 do $11,5^{\circ} \mathrm{C}$.

Možen vzrok za vegetacijski obrat v Najenu so lahko tudi slabši talni pogoji, saj se z vzhodnih pobočij vanj spušča vršaj, iz katerega vode izpirajo fine delce (t.i. kredo), ki se akumulira na dnu depresije.

Na slabše rastiščne pogoje na dnu depresije kažejo tudi terminalni poganjki pri smrekah. Na dnu so bili poganjki ob koncu višinskega priraščanja 23.6.1992 v povprečju visoki $3,5 \mathrm{~cm}$, na robu depresije pa $6,2 \mathrm{~cm}$.

Višinski prirast pri smrekah se na splošno znižuje tudi po dnu doline v smeri od Rateč (n.v. $860 \mathrm{~m}$ ) do zgornje drevesne meje v Malem kotu pod Jalovčevim ozebnikom (n.v. 1420 m). Po meritvah na devetih vzorčnih lokacijah 23.6.1992 je gradient višinskega prirastka med Ratečami in Malim kotom znašal $-3,9 \mathrm{~cm} / 100 \mathrm{~m}$. Poudariti pa velja, da je to splošen trend in da so bili poganjki na nekaterih lokacijah s sicer nižjo nadmorsko višino, a slabšimi talnimi razmerami krajši, kot pa na lokacijah z višjo nadmorsko višino, toda boljšimi talnimi pogoji.

Navkljub tem anomalijam pa lahko na osnovi meritev terminalnih poganjkov iz začetka junija 1990 in konca junija 1993 planiško dolino po vzdolžnem profilu razčlenimo na štiri fitofenološke cone, ki so povezane $\mathrm{z}$ bolj ali manj izrazitimi 
reliefnimi skoki v pokrajini. Najugodnejše rastne pogoje ima spodnji del doline med Ratečami in Ranci (do n.v. okoli 1000 m), kjer je bila povprečna dolžina terminalnih poganjkov pri smrekah višja od $15 \mathrm{~cm}$.

$\mathrm{V}$ osrednjem delu doline, med n.v. 1000 in $1100 \mathrm{~m}$ (ta del vključuje tudi mrazišče Najen), so bili poganjki dolgi 10 do $15 \mathrm{~cm}$. V okolici planinskega doma Tamar (n.v. 1100 do $1160 \mathrm{~m}$ ) je bila povprečna dolžina poganjkov med 5 in $10 \mathrm{~cm}$. Najostrejše razmere, z najslabšimi (tudi klimatskimi) pogoji za rast so $v$ zgornjem koncu planiške doline nad n.v. $1160 \mathrm{~m}$. Tu so bili terminalni poganjki v povprečju krajši od $5 \mathrm{~cm}$. K slabšim rastiščnim razmeram in krajši vegetacijski dobi $v$ tem koncu doline veliko prispeva tudi snežna odeja, ki se zaradi plazenja z višjih predelov zadržuje pozno v pomlad.

\subsubsection{Prečni profil čez dolino}

Temperaturne meritve na prečnem profilu čez dolino so potekale $v$ višini planinskega doma Tamar. Na zahodnem pobočju smo merili ob planinski poti na Ponce, na vzhodnem pa ob poti na Sleme.

$\mathrm{Na}$ zahodnem pobočju so temperature 26.6 .1992 , ob spustu z n.v. $1720 \mathrm{~m}$ do koče (n.v. $1106 \mathrm{~m}$ ), med 12.05 in 13.43 , ob pretežno jasnem in sončnem vremenu, $v$ povprečju naraščale s stopnjo $0,79^{\circ} \mathrm{C} / 100 \mathrm{~m}$. Gradient je splošna tendenca, saj so temperature zelo nihale v odvisnosti od stopnje oblačnosti in vetrovnih razmer (tabela 6).

Tabela 6: Spreminjanje temperatur z nadmorsko višino na zahodnem pobočju planiške doline ob planinski poti na Ponce 26.6.1992.

\begin{tabular}{ccc}
\hline $\begin{array}{c}\text { Nad. višina } \\
(\mathrm{m})\end{array}$ & Čas meritev & $\begin{array}{c}\text { Temperatura } \\
\left({ }^{\circ} \mathrm{C}\right)\end{array}$ \\
\hline 1720 & 12,05 & 15,5 \\
1650 & 12,15 & $12,4-13,0$ \\
1610 & 12,20 & $15,6-16,4$ \\
1550 & 12,25 & 14,6 \\
1500 & 12,30 & 16,6 \\
1450 & 12,35 & 18,8 \\
1400 & 12,43 & 15,5 \\
1350 & 13,15 & 15,3 \\
1300 & 13,20 & 15,2 \\
1250 & 13,25 & 17,6 \\
1200 & 13,30 & 19,6 \\
1150 & 13,38 & 16,9 \\
1100 & 13,50 & 19,9 \\
\hline
\end{tabular}


Nižji temperaturni gradient $(0,33 \mathrm{st} / 100 \mathrm{~m})$ smo izračunali za meritve pri spustu $\mathrm{s}$ Slemena (n.v. $1782 \mathrm{~m}$ ) do koče Tamar. Meritve so potekale 30.6.1993, med 13.50 in 14.50 , ob pretežno jasnem in sončnem vremenu (tabela 7).

Tabela 7: Spreminjanje temperatur z nadmorsko višino na vzhodnem pobočju planiške doline ob planinski poti na Sleme 30.6.1993.

\begin{tabular}{ccc}
\hline $\begin{array}{c}\text { Nad. višina } \\
(\mathrm{m})\end{array}$ & Čas meritev & $\begin{array}{c}\text { Temperatura } \\
\left({ }^{\circ} \mathrm{C}\right)\end{array}$ \\
\hline 1782 & 13,50 & 18,1 \\
1700 & 13,55 & 17,0 \\
1660 & 14,00 & 20,5 \\
1600 & 14,07 & 20,0 \\
1550 & 14,15 & 20,5 \\
1450 & 14,20 & 20,0 \\
1350 & 14,25 & 21,0 \\
1275 & 14,35 & 17,4 \\
1200 & 14,45 & 18,6 \\
1175 & 14,50 & 22,1 \\
\hline
\end{tabular}

Podobno kot pri vzdolžnem profilu, so nas tudi pri prečnem profilu čez dolino zanimale spremembe $v$ višinskem priraščanju. Merili smo smreke in macesne, saj obe vrsti rasteta do zgornje drevesne meje. Meritve so potekale med 22. in 26.6.1992.

Na zahodnem pobočju planiške doline, med planinskim domom Tamar in zgornjo drevesno mejo pod Poncami (n.v. $1720 \mathrm{~m}$ ), je znašal gradient zmanjšanja višinskega prirastka $\mathrm{z}$ višino pri smreki $-1,6 \mathrm{~cm} / 100 \mathrm{~m}$, pri macesnu, ki je imel na splošno krajše poganjke pa $-0,5 \mathrm{~cm} / 100 \mathrm{~m}$. Iz rezultatov meritev (tabela 8 ) je razvidno, da se je dolžina terminalnih poganjkov pri smreki z višino enakomerno zmanjševala. Pri macesnih pa smo ugotovili neke vrste "prirastno inverzijo". Na izrazito prisojnem pobočju, na n.v. med 1330 in $1380 \mathrm{~m}$, je bila povprečna dolžina poganjkov $6,6 \mathrm{~cm}$, dobrih $200 \mathrm{~m}$ nižje $4,8 \mathrm{~cm}$, v dnu doline pa $5,7 \mathrm{~cm}$. Daljši poganjki na višji nadmorski višini, ob na prvi pogled podobnih rastiščnih pogojih, so verjetno posledica boljših svetlobnih razmer, saj je macesen izrazito heliofilna drevesna vrsta.

Nekoliko manj jasen je trend upadanja višinskega priraščanja $\mathrm{z}$ nadmorsko višino na vzhodnem delu profila proti Slemenu. Trend zamegljuje izrazita inverznost v priraščanju, ki je posledica zelo različnih talnih razmer. Vsa merilna mesta, razen najvišjega na Slemenu, so bila na bolj ali manj aktivnem vršajsko-meliščnem gradivu, s slabo razvitimi prstmi. Odeja prsti je bila bolj razvita in sklenjena le Pod slatnami, 
zato smo tu, če zanemarimo rezultate iz dna doline, namerili najdaljše poganjke. Pri nižje ležeči lokaciji so bili poganjki krajši, medtem ko smreke in macesni na Slemenu na dan meritev še niso odgnali. Zelo opazno je tudi dejstvo, da so bili terminalni poganjki na vzhodnem delu profila bistveno krajši, kot na zahodnem delu.

Tabela 8: Dolžina terminalnih poganjkov na profilu Zadnja Ponca-Sleme (22.-26.6.1992).

\begin{tabular}{lcccl}
\hline Ime lokacije & Nadm. viš. & \multicolumn{2}{c}{ Dol. term. pog. $(\mathrm{cm})$} & \\
& $(\mathrm{m})$ & Smreka & Macesen & \\
\hline Pod Ponco & 1720 & 0,7 & 2,6 & \\
Pri nagnoju & 1355 & 6,3 & 6,6 & zahodno \\
Pri plazu & 1115 & 9,4 & 4,8 & pobočje \\
\hline Koča Tamar & 1108 & 10,5 & 5,7 & dno doline \\
\hline Črna voda & 1130 & 2,8 & 4,0 & vzhodno \\
Pod slatnami & 1600 & 5,5 & 2,4 & pobočje \\
Sleme & 1800 & 0,0 & 0,0 & \\
\hline
\end{tabular}

\subsection{Lokalna zračna cirkulacija}

$\mathrm{Ob}$ jasnem stabilnem vremenu, brez močnejših splošnih vetrov, prihaja zaradi razlik v obsijanosti s soncem (slika 2) v dolini Planice do lokalne zračne cirkulacije, ki je značilna za alpske doline. Zahodno pobočje doline, ki se vzpenja proti Poncam, je v jutranjih urah obsijano s soncem, zato se zrak ob njem dviga. Nasprotno pa se z vzhodnih, osojnih pobočij hladnejši zrak spušča $v$ dolino in odteka proti glavni dolini.

Po meritvah 2. in 3.6.1988 med 8. in 9.30 so bile hitrosti vzgonskega vetra po prisojnem pobočju $v$ zgornjem koncu planiške doline med 0,3 in $1,9 \mathrm{~m} / \mathrm{s}$, spuščajočega se vetra $v$ osojah pa med 0,7 in $1,5 \mathrm{~m} / \mathrm{s}$. Temperaturna razlika med obema pobočjema je znašala do $5,5^{\circ} \mathrm{C}$ (slika 3 ). Energija sončnega obsevanja, izračunana s pomočjo računalniškega programa Sonček (M. Krevs, M. Gabrovec, 1988-91) za 21.6. ob 7. uri, znaša npr. za lokacijo "Spodmoli" (n.v. 1300 m) na prisojnem pobočju nad kočo v Tamarju $0,397 \mathrm{kWh} / \mathrm{m}^{2}$, za osojno "Črno vodo" (n.v. $1220 \mathrm{~m}$ ) pa le $0,086 \mathrm{kWh} / \mathrm{m}^{2}$.

Čez dan je bila oba dneva meritev vetrov bolj zapletena, saj je veter zelo pogosto menjaval smeri. V večernih urah, ko je sonce zašlo za horizont, pa se je začel hladen zrak stekati z višjih pobočij $v$ dolino in po njej odtekati proti glavni savski dolini. Hitrosti vetra so bile majhne, med 0,3 do $0,9 \mathrm{~m} / \mathrm{s}$ (slika 4). Stekanje hladnega zraka s pobočij je trajalo vso noč. Po opazovanju na vegetaciji je bilo najmočnejše $v$ zgodnjih jutranjih urah pred sončnim vzhodom. 
Slika 3: Lokalni vetrovi v južnem delu Planice 2.6.1988 med 8. in 9. uro zjutraj.

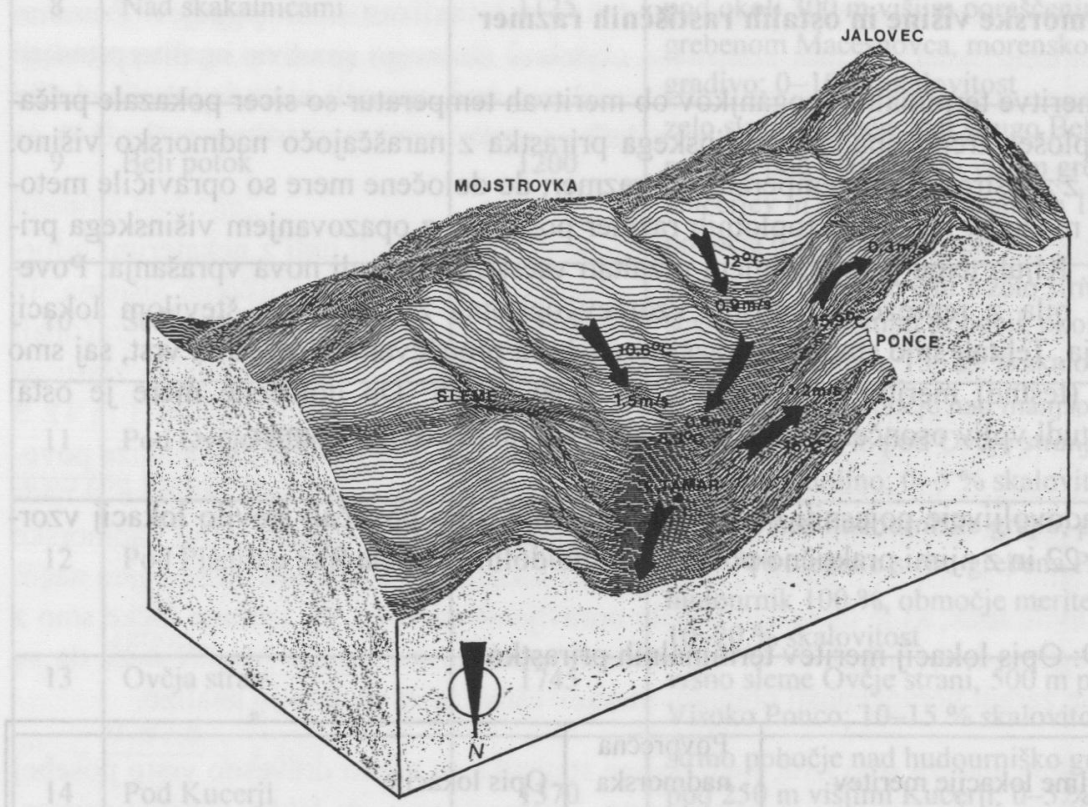

Slika 4: Lokalni vetrovi v južnem delu Planice 2.6.1988 med 18. in 19. uro.

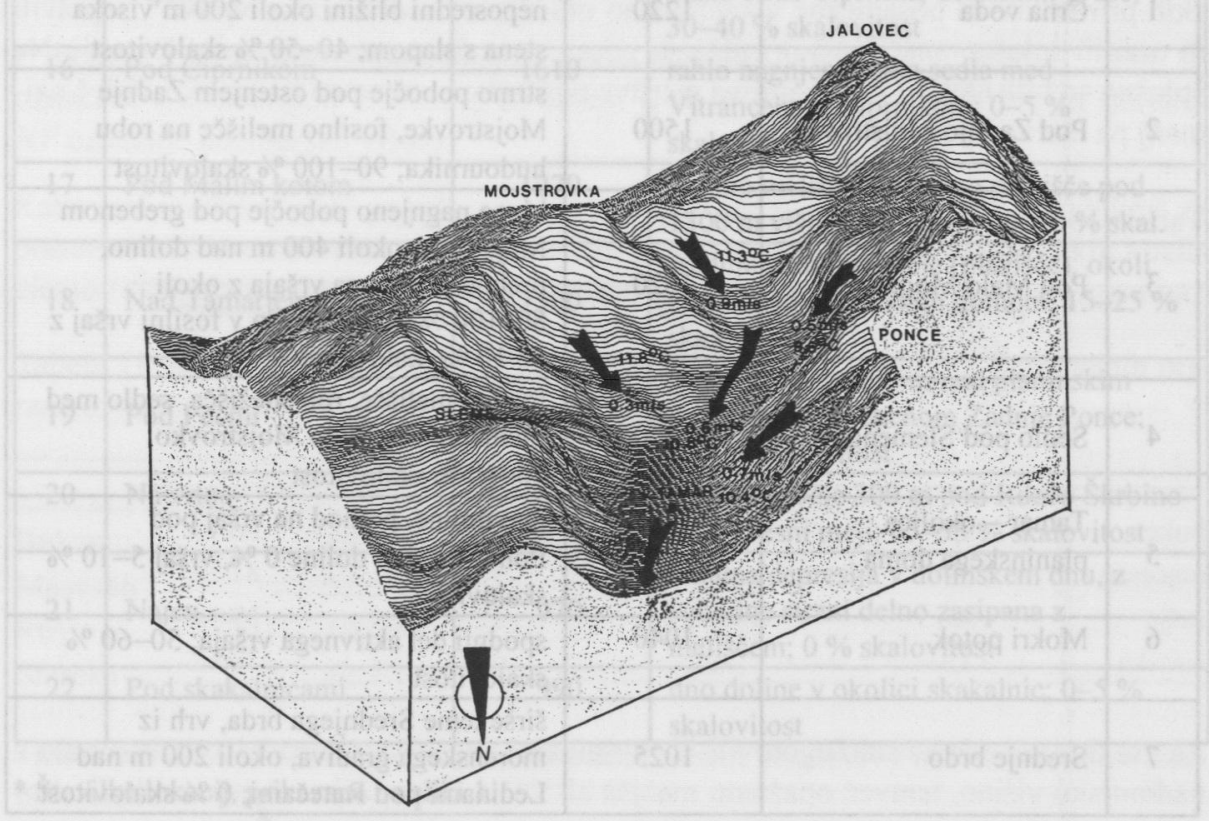




\subsection{Prispevek k poznavanju višinskega prirastka dreves v Planici kot funkcije nadmorske višine in ostalih rastiščnih razmer}

Testne meritve terminalnih poganjkov ob meritvah temperatur so sicer pokazale pričakovan splošen trend upadanja višinskega prirastka $\mathrm{z}$ naraščajočo nadmorsko višino, oziroma z zaostrovanjem temperaturnih razmer; do določene mere so opravičile metodološko možnost raziskave toplotnih razmer posredno $\mathrm{z}$ opazovanjem višinskega priraščanja. Kljub temu pa so dobljeni rezultati vseskozi odpirali nova vprašanja. Povezana so bila $\mathrm{z}$ reprezentativnostjo vzorcev oziroma $\mathrm{z}$ zadostnim številom lokacij vzorčenja. Tehtali smo smotrnost razširitve izbora proučevanih drevesnih vrst, saj smo prvotne (testne) meritve opravljali le na dveh vrstah. Do določene mere je ostal nejasen tudi vpliv osončenja (ekspozicije) ter talnih rastiščnih razmer.

Da bi zadovoljiveje pojasnili omenjena vprašanja, smo povečali število lokacij vzorčenja na 22 in z njimi praktično pokrili celotno dolino (tabela 9).

Tabela 9: Opis lokacij meritev terminalnih prirastkov.

\begin{tabular}{|c|l|c|l|}
\hline Št.* & Ime lokacije meritev & $\begin{array}{c}\text { Povprečna } \\
\text { nadmorska } \\
\text { višina }(\mathrm{m})\end{array}$ & Opis lokacije \\
\hline 1 & Črna voda & 1220 & $\begin{array}{l}\text { prehod talne morene v fosilno melišče, v } \\
\text { neposredni bližini okoli } 200 \text { m visoka } \\
\text { stena s slapom; } 40-50 \% \text { skalovitost }\end{array}$ \\
\hline 2 & Pod Zadnjo Mojstrovko & 1500 & $\begin{array}{l}\text { strmo pobočje pod ostenjem Zadnje } \\
\text { Mojstrovke, fosilno melišče na robu } \\
\text { hudournika; } 90-100 \% \text { skalovitost }\end{array}$ \\
\hline 3 & Pod Malo Mojstrovko & 1620 & $\begin{array}{l}\text { blago nagnjeno pobočje pod grebenom } \\
\text { prehod aktivnega vršaja z okoli } \\
80-100 \% \text { skalovitostjo v fosilni vršaj z } \\
\text { do 10\% skalovitosti }\end{array}$ \\
\hline 4 & Sedlo pod Slemenom & 1770 & $\begin{array}{l}\text { fosilno melišče, rob snežišča, sedlo med } \\
\text { Slemenom in Malo Mojstrovko; } \\
20-30 \% \text { skalovitost }\end{array}$ \\
\hline 7 & $\begin{array}{l}\text { Tamar - okolica } \\
\text { planinskega doma }\end{array}$ & 1100 & $\begin{array}{l}\text { dno doline, prehod na vršaj pod } \\
\text { Poncami; dno doline 0 \%, vršaj 5-10\% } \\
\text { skalovitost }\end{array}$ \\
\hline 6 & Mokri potok & 1025 & $\begin{array}{l}\text { spodnji del aktivnega vršaja; } 50-60 \% \\
\text { skalovitost }\end{array}$ \\
\hline
\end{tabular}




\begin{tabular}{|c|c|c|c|}
\hline 8 & Nad skakalnicami & 1125 & $\begin{array}{l}\text { blago nagnjeno površje na temenu Drnic, } \\
\text { pod okoli } 300 \mathrm{~m} \text { višjim poraščenim } \\
\text { grebenom Macesnovca, morensko } \\
\text { gradivo; } 0-10 \% \text { skalovitost }\end{array}$ \\
\hline 9 & Beli potok & 1200 & $\begin{array}{l}\text { zelo strmo pobočje nad strugo Belega } \\
\text { potoka, pod } 300-400 \mathrm{~m} \text { višjim grebenom } \\
\text { Kucerjev in Macesnovca; struga } 100 \% \text {, } \\
\text { pobočja } 0-5 \% \text { skalovitost }\end{array}$ \\
\hline 10 & Sedlo pod Glavami & 1375 & $\begin{array}{l}\text { skalni rob pod Glavami z zelo strmimi } \\
\text { severnimi in južnimi pobočji, okoli } \\
300 \mathrm{~m} \text { nad dolino; } 15-25 \% \text { skalovitost }\end{array}$ \\
\hline 11 & Pod Ovčjo stranjo & 1525 & $\begin{array}{l}\text { srednje strmo pobočje nad manjšo } \\
\text { uravnavo, } 200 \mathrm{~m} \text { pod Ovčjo stranjo, } \\
450 \mathrm{~m} \text { nad dolino; } 0-5 \% \text { skalovitost }\end{array}$ \\
\hline 12 & Pod Planiško Škrbino & 1600 & $\begin{array}{l}\text { pobočje nad hudourniško grapo, pod } \\
600-700 \text { metrsko steno grebena Ponc; } \\
\text { hudournik } 100 \% \text {, območje meritev } \\
10-20 \% \text { skalovitost }\end{array}$ \\
\hline 13 & Ovčja stran & 1745 & $\begin{array}{l}\text { vršno sleme Ovčje strani, } 500 \mathrm{~m} \text { pod } \\
\text { Visoko Ponco; } 10-15 \% \text { skalovitost }\end{array}$ \\
\hline 14 & Pod Kucerji & 1370 & $\begin{array}{l}\text { strmo pobočje nad hudourniško grapo, } \\
\text { pod } 250 \mathrm{~m} \text { višjimi Kucerji; } 0-5 \% \\
\text { skalovitost }\end{array}$ \\
\hline 15 & Ciprnik & 1745 & $\begin{array}{l}\text { vršno teme Ciprnika, dolomitni grušč; } \\
30-40 \% \text { skalovitost }\end{array}$ \\
\hline 16 & Pod Ciprnikom & 1610 & $\begin{array}{l}\text { rahlo nagnjeno teme sedla med } \\
\text { Vitrancem in Ciprnikom; } 0-5 \% \\
\text { skalovitost }\end{array}$ \\
\hline 17 & Pod Malim kotom & 1270 & $\begin{array}{l}\text { fosilno melišče in snežno plazišče pod } \\
1300 \text { m višjim Jalovcem; } 40-50 \% \text { skal. }\end{array}$ \\
\hline 18 & Nad Tamarjem & 1300 & $\begin{array}{l}\text { srednje strmo pobočje (plazišče), okoli } \\
200 \text { m nad planinskim domom; } 15-25 \% \\
\text { skalovitost }\end{array}$ \\
\hline 19 & Pod Pečmi & 1525 & $\begin{array}{l}\text { strmo pobočje } 400 \mathrm{~m} \text { nad planinskim } \\
\text { domom, pod grebenom Zadnje Ponce; } \\
0-5 \% \text { skalovitost }\end{array}$ \\
\hline 20 & Na vrtcu & 1850 & $\begin{array}{l}\text { strmo pobočje } 300 \mathrm{~m} \text { pod Rdečo Škrbino } \\
\text { na drevesni meji; } 45-55 \% \text { skalovitost }\end{array}$ \\
\hline 21 & Najen & 970 & $\begin{array}{l}\text { lokalna depresija v dolinskem dnu, } \mathrm{z} \\
\text { vzhodne strani delno zasipana } \mathrm{z} \\
\text { meliščem; } 0 \% \text { skalovitost }\end{array}$ \\
\hline 22 & Pod skakalnicami & 990 & $\begin{array}{l}\text { dno doline v okolici skakalnic; } 0-5 \% \\
\text { skalovitost }\end{array}$ \\
\hline
\end{tabular}

* Stevilke lokacij, prikazane na sliki 1. 
Raziskavo smo z macesnov in smrek razširili še na bukev in rušje. V primerjavi s testnimi meritvami smo večji poudarek dali opredelitvi rastiščnih pogojev. Posebno pozornost smo namenili tudi statistični obdelavi zbranega gradiva in interpretaciji dobljenih rezultatov. Meritve za ta del raziskave smo opravili $\vee$ prvi polovici julija 1994. Skupno smo izmerili 1397 terminalnih poganjkov, od tega 440 na rušju, 343 na macesnu, 325 na smreki in 289 na bukvi.

$\mathrm{Za}$ opis lokacij smo izsledke terenskega opazovanja dopolnili tudi z nekaterimi informacijami, ki smo jih pridobili s pomočjo geografskega informacijskega sistema. Iz digitalnega modela reliefa (DMR 100, 1992) smo s pomočjo interpolacije izračunali podrobnejši DMR s celicami velikosti $20 \times 20$ metrov. Potrebovali smo ga zlasti za nazornejši prostorski (trirazsežnostni) prikaz obravnavanega območja (sliki 3 in 4). S karte $1: 25.000$ smo digitalizirali območja meritev. Za kasnejšo izvedbo analize povezanosti prirastkov in nadmorske višine smo namreč potrebovali tudi podatke o nadmorski višini za posamezna drevesa. Ker teh meritev nismo izvajali, smo nadmorske višine ocenili na naslednji način. Znotraj vsake lokacije meritev smo na slučajen način izbrali število točk, ki je ustrezalo številu opravljenih meritev. Za izbrane točke smo z omenjenega podrobnejšega DMR-ja "odčitali" nadmorsko višino. Menili smo, da so bile ocene zaradi homogenosti območij meritev ustrezne za nadaljnjo analizo.

V prvem delu analize smo izračunali opisne statistike za vsako drevesno vrsto posebej (tabela 10) in za posamezna merilna mesta. Ugotovili smo, da lahko meritve primerkov iste vrste na posamezni lokaciji močno variirajo. $Z$ računanjem povprečij višinskih prirastkov za posamezne lokacije smo omenjene "individualne vplive" odpravili in ocenili splošno značilnost priraščanja posamezne drevesne vrste na tej lokaciji. Na splošno so bile najbolj spremenljive meritve poganjkov macesna in smreke, daleč najmanj pa meritve poganjkov rušja.

Tabela 10: Opisne statistike meritev terminalnih poganjkov.

\begin{tabular}{lcccc}
\hline & $\begin{array}{c}\text { povprečna } \\
\text { dolžina } \\
\text { poganjkov } \\
(\mathrm{cm})\end{array}$ & $\begin{array}{c}\text { najmanjša } \\
\text { izmerjena } \\
\text { dolžina } \\
\text { poganjkov } \\
(\mathrm{cm})\end{array}$ & $\begin{array}{c}\text { največja } \\
\text { izmerjena } \\
\text { dolžina } \\
\text { poganjkov } \\
(\mathrm{cm})\end{array}$ & $\begin{array}{c}\text { koeficient } \\
\text { variacije }\end{array}$ \\
\hline bukev & 18,6 & 3,5 & 67,0 & $56 \%$ \\
macesen & 10,0 & 0,0 & 48,0 & $81 \%$ \\
rušje & 8,6 & 2,5 & 22,0 & $39 \%$ \\
smreka & 12,3 & 1,5 & 66,0 & $79 \%$ \\
\hline
\end{tabular}

Za vse drevesne vrste smo ugotovili, da terminalni poganjki ne upadajo enakomerno $\mathrm{z}$ nadmorsko višino, temveč opažamo manjša ali večja odstopanja meritev od "pričako- 
vane" dolžine poganjkov. Slednjo smo ocenili s pomočjo regresijske metode, ki smo jo izvedli v drugem delu analize. Ugotovili smo, da se podatkom za bukev in smreko najbolje prilega inverzna (obratna) funkcija, za rušje in macesen pa so rezultati nekoliko boljši pri uporabi linearne funkcije. Navedene regresijske funkcije smo izračunali na podlagi posameznih meritev (ne na podlagi povprečij za lokacije):

linearne funkcije:

$P_{B}^{\prime}=-0,358 . \mathrm{NV}+64,198$

$P_{M}^{\prime}=-0,328 . \mathrm{NV}+56,373$

$P_{K}^{\prime}=-0,0066 . \mathrm{NV}+17,826$

$P_{S}^{\prime}=-0,0266 . \mathrm{NV}+47,470$

inverzne funkcije:

$P_{B}^{\prime}=\frac{58568,2}{N V}-28,782$

$P_{M}^{\prime}=\frac{48990,7}{N V}-25,082$

$P_{R}^{\prime}=\frac{9797,8}{N V}+1,469$

$P_{S}^{\prime}=\frac{42042,6}{N V}-20,389$

$P^{\prime}$ pomeni oceno dolžine poganjka določene drevesne vrste ( $v$ centimetrih). Vrste so označene $\mathrm{z}$ naslednjimi indeksi: $\mathrm{B}$ za bukev, $\mathrm{M}$ za macesen, $\mathrm{R}$ za rušje in $\mathrm{s}$ za smreko. $N V$ označuje nadmorsko višino.

Kakovost modelov nam pokaže preglednica deležev variance dolžine poganjkov za posamezno drevesno vrsto, $\mathrm{ki}$ jo pojasnjuje model na podlagi determinacijskih koeficientov $r^{2}$. Vsi navedeni modeli so statistično pomembni z manj kot $0,1 \%$ tveganjem.

Tabela 11: Kakovost* regresijskih modelov za napovedovanje dolžine terminalnih prirastkov na podlagi nadmorske višine.

\begin{tabular}{lcc}
\hline & Linearna funkcija & Inverzna funkcija \\
\hline Bukev & $49,2 \%$ & $58,1 \%$ \\
Macesen & $52,9 \%$ & $52,2 \%$ \\
Rušje & $18,0 \%$ & $17,5 \%$ \\
Smreka & $42,1 \%$ & $46,6 \%$ \\
\hline
\end{tabular}

* Kakovost izražena $\mathrm{z}$ deležem pojasnjene variance dolžine prirastkov $\mathrm{z}$ nadmorsko višino lokacij meritev. 
Čeprav za bukev in smreko dajeta boljše ocene inverzna modela, lahko linearne modele za vse vrste dreves uporabimo za oceno vertikalnega gradienta zmanjšanja višinskega priraščanja. To oceno kažejo regresijski koeficienti, ki nam povedo, da so na 100 metrov višje ležečem rastišču poganjki v povprečju krajši za $3,58 \mathrm{~cm}$ pri bukvi, za $3,28 \mathrm{~cm}$ pri macesenu, za $0,66 \mathrm{~cm}$ pri rušju in za $2,66 \mathrm{~cm}$ pri smreki.

$\mathrm{V}$ tretjem delu analize smo primerjali ocene modelov, ki ponazarjajo pričakovane dolžine poganjkov, z izmerjenim letnim višinskim prirastkom posameznih dreves. Izračunali smo povprečna odstopanja višinskega prirastka posamezne vrste dreves za vsako lokacijo meritev posebej. Odstopanja smo izrazili tudi $v$ odstotkih od povprečja izmerjene dolžine terminalnih poganjkov na posamezni lokaciji ter $\mathrm{s}$ tem omogočili lažjo primerljivost med lokacijami meritev in med različnimi drevesnimi vrstami. Na podlagi teh izračunov smo poskušali razlagati vplive rastiščnih pogojev na letni višinski prirast.

\subsubsection{Vrednotenje rezultatov}

Splošna in pričakovana ugotovitev za vse analizirane drevesne vrste je, da se dolžina terminalnih poganjkov $\mathrm{z}$ naraščajočo nadmorsko višino $\mathrm{v}$ povprečju zmanjšuje (slike $5,6,7,8)$. Gradienti pa niso za vse drevesne vrste enaki in tudi ne enakomerni. Pri bukvi smo ugotovili najbolj izrazit padec dolžine terminalnih poganjkov $\mathrm{v}$ spodnjem delu doline, toda brez izrazite povezave z nadmorsko višino. Nad $1100 \mathrm{~m}$, to je nad dolinskim dnom, je upad zmeren. $V$ najvišjih legah, kjer smo bukev še našli - n.v. nad 1500 m (lokacije "Pod Pečmi", "Pod Ciprnikom", "Pod Malo Mojstrovko") smo izmerili sorazmerno visoke vrednosti, kar si razlagamo s sorazmerno dobrimi talnimi razmerami na teh lokacijah oz. z manjšo skalovitostjo površja. Poudariti pa velja, da je bilo na najvišje ležečih lokacijah ("Pod Ciprnikom", "Pod Planiško Škrbino") opravljenih tudi manj meritev, ker je bukev tu že zelo slabo zastopana. Od pričakovanj so pri bukvi rezultati najbolj odstopali na lokaciji "Mokri potok", kjer je bil višinski prirast močno pod pričakovanim zaradi vplivov aktivnega vršaja.

$\mathrm{V}$ dolinskem dnu, razen $\vee$ okolici planinskega doma Tamar, nismo našli zadostnega števila ustreznih macesnov. $V$ večjem številu se začno pojavljati šele nad višino $1200 \mathrm{~m}$. Do višine okoli $1300 \mathrm{~m}$ beležimo izrazito upadanje dolžine poganjkov. Od tega trenda izjemno odstopajo meritve "Nad Tamarjem", kjer so bile izmerjene vrednosti v povprečju dobrih $5 \mathrm{~cm}$ višje, kot bi pričakovali. Odstopanje težko pojasnimo $\mathrm{z}$ vidika talnih ugodnosti rastišča, verjetno je pomemben dejavnik redkost in dobra osvetljenost drevesnega sestoja, $v$ katerem smo vzorčili. Nad omenjeno višino dolžina poganjkov komaj zaznavno upada, okoli višine $1600 \mathrm{~m}$, t.j. na višini zgornje gozdne meje, pa na dveh lokacijah celo znatno naraste. Na Ciprniku na primer izmerjene vrednosti v povprečju dosegajo tiste izmerjene $400 \mathrm{~m}$ niže. 


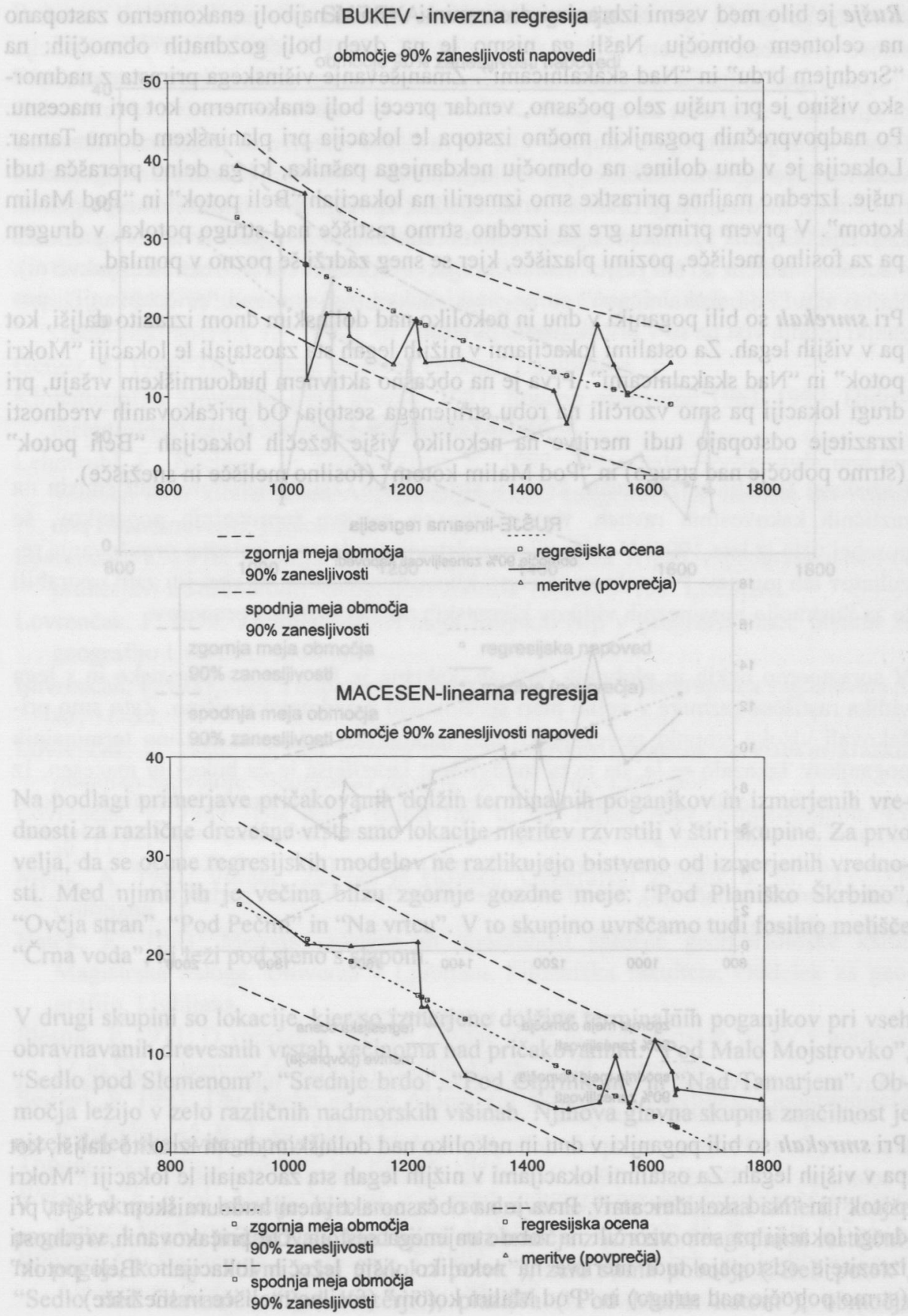


Rušje je bilo med vsemi izbranimi drevesnimi vrstami najbolj enakomerno zastopano na celotnem območju. Našli ga nismo le na dveh bolj gozdnatih območjih: na "Srednjem brdu" in "Nad skakalnicami". Zmanjševanje višinskega prirasta z nadmorsko višino je pri rušju zelo počasno, vendar precej bolj enakomerno kot pri macesnu. Po nadpovprečnih poganjkih močno izstopa le lokacija pri planinskem domu Tamar. Lokacija je $v$ dnu doline, na območju nekdanjega pašnika, ki ga delno prerašča tudi rušje. Izredno majhne prirastke smo izmerili na lokacijah "Beli potok" in "Pod Malim kotom". V prvem primeru gre za izredno strmo rastišče nad strugo potoka, $v$ drugem pa za fosilno melišče, pozimi plazišče, kjer se sneg zadrži še pozno v pomlad.

Pri smrekah so bili poganjki v dnu in nekoliko nad dolinskim dnom izrazito daljši, kot pa v višjih legah. Za ostalimi lokacijami v nižjih legah sta zaostajali le lokaciji "Mokri potok" in "Nad skakalnicami". Prva je na občasno aktivnem hudourniškem vršaju, pri drugi lokaciji pa smo vzorčili na robu strnjenega sestoja. Od pričakovanih vrednosti izraziteje odstopajo tudi meritve na nekoliko višje ležečih lokacijah "Beli potok" (strmo pobočje nad strugo) in "Pod Malim kotom" (fosilno melišče in snežišče).

\section{RUŠJE-linearna regresija}

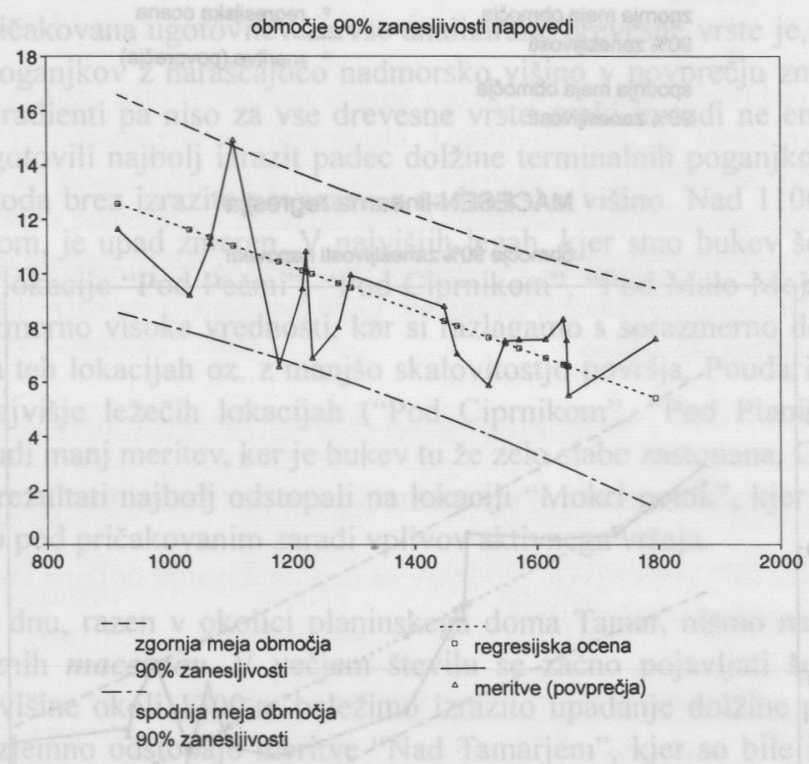

Pri smrekah so bili poganjki $v$ dnu in nekoliko nad dolinskim dnom izrazito daljši, kot pa v višjih legah. Za ostalimi lokacijami v nižjih legah sta zaostajali le lokaciji "Mokri potok" in "Nad skakalnicami". Prva je na občasno aktivnem hudourniškem vršaju, pri drugi lokaciji pa smo vzorčili na robu strnjenega sestoja. Od pričakovanih vrednosti izraziteje odstopajo tudi meritve na nekoliko višje ležečih lokacijah "Beli potok" (strmo pobočje nad strugo) in "Pod Malim kotom" (fosilno melišče in snežišče). 


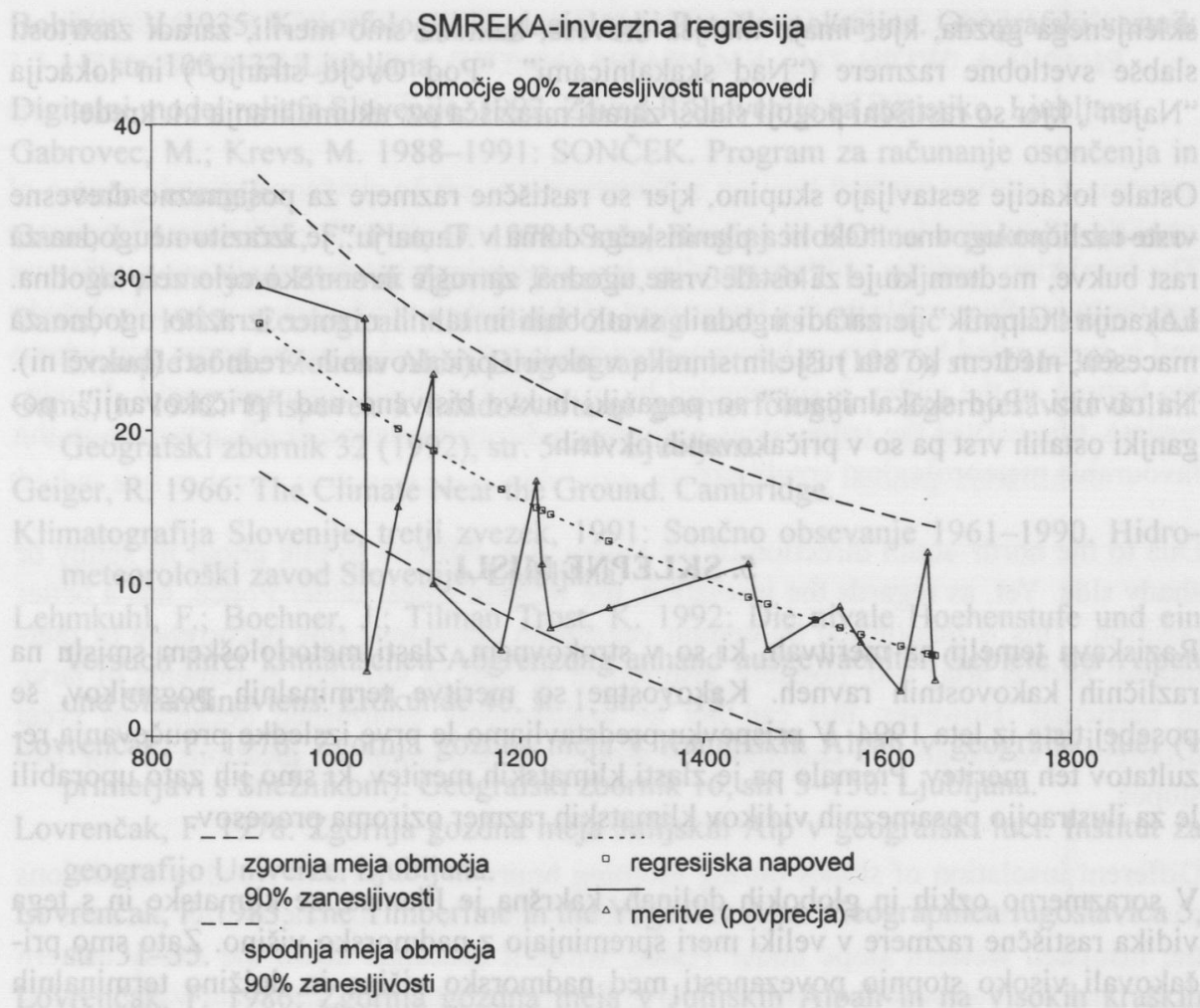

Na podlagi primerjave pričakovanih dolžin terminalnih poganjkov in izmerjenih vrednosti za različne drevesne vrste smo lokacije meritev rzvrstili v štiri skupine. Za prvo velja, da se ocene regresijskih modelov ne razlikujejo bistveno od izmerjenih vrednosti. Med njimi jih je večina blizu zgornje gozdne meje: "Pod Planiško Škrbino", "Ovčja stran", "Pod Pečmi" in "Na vrtcu". V to skupino uvrščamo tudi fosilno melišče "Črna voda", ki leži pod steno s slapom.

V drugi skupini so lokacije, kjer so izmerjene dolžine terminalnih poganjkov pri vseh obravnavanih drevesnih vrstah večinoma nad pričakovanimi: "Pod Malo Mojstrovko", "Sedlo pod Slemenom", "Srednje brdo", "Pod Ciprnikom" in "Nad Tamarjem". Območja ležijo $v$ zelo različnih nadmorskih višinah. Njihova glavna skupna značilnost je nizek delež skalovitega površja.

V tretji skupini so lokacije, kjer smo za vse drevesne vrste večinoma izmerili krajše poganjke, kot smo pričakovali. Med njimi so območja z izrazito neugodnimi rastiščnimi pogoji, kot so aktivni vršaj ("Mokri potok"), zelo strma pobočja ("Beli potok", "Sedlo nad Glavami", "Pod Kucerji"), plazišča ("Pod Malim kotom"), območja 
sklenjenega gozda, kjer imajo manjša drevesa, kakršna smo merili, zaradi zastrtosti slabše svetlobne razmere ("Nad skakalnicami", "Pod Ovčjo stranjo") in lokacija "Najen", kjer so rastiščni pogoji slabši zaradi mrazišča oz. akumuliranja t.i. krede.

Ostale lokacije sestavljajo skupino, kjer so rastiščne razmere za posamezne drevesne vrste različno ugodne. "Okolica planinskega doma v Tamarju" je izrazito neugodna za rast bukve, medtem ko je za ostale vrste ugodna, za rušje in smreko celo zelo ugodna. Lokacija "Ciprnik" je zaradi ugodnih svetlobnih in talnih razmer izrazito ugodno za macesen, medtem ko sta rušje in smreka $v$ okviru pričakovanih vrednosti (bukve ni). $\mathrm{Na}$ ravnici "Pod skakalnicami" so poganjki bukve bistveno nad "pričakovanji", poganjki ostalih vrst pa so v pričakovanih okvirih.

\section{SKLEPNE MISLI}

Raziskava temelji na meritvah, ki so v strokovnem, zlasti metodološkem smislu na različnih kakovostnih ravneh. Kakovostne so meritve terminalnih poganjkov, še posebej tiste iz leta 1994 . V prispevku predstavljamo le prve izsledke proučevanja rezultatov teh meritev. Premalo pa je zlasti klimatskih meritev, ki smo jih zato uporabili le za ilustracijo posameznih vidikov klimatskih razmer oziroma procesov.

V sorazmerno ozkih in globokih dolinah, kakršna je Planica, se klimatske in s tega vidika rastiščne razmere $\mathrm{v}$ veliki meri spreminjajo $\mathrm{z}$ nadmorsko višino. Zato smo pričakovali visoko stopnjo povezanosti med nadmorsko višino in dolžino terminalnih poganjkov. Izkazalo se je, da je ta soodvisnost izrazitejša le za bukev in macesen. Iz tega bi lahko sledilo, da bi ti dve vrsti predlagali kot bolj ustrezna indikatorja mikroklimatskih razmer. Ker pa $\mathrm{v}$ dosedanji raziskavi nismo podrobneje upoštevali heterogenosti doline z vidika posameznih rastiščnih pogojev (npr. litološke sestave, reliefne oblikovanosti, osončenja), bomo tovrstne zaključke poskušali podati šele $v$ nadaljevanju raziskave.

\section{VIRI IN LITERATURA}

Arhiv HMZ Slovenije: Klimatski podatki za meteorološko postajo Rateče-Planica v obdobju 1961-1990. Ljubljana.

Baccetti, B. 1989: Biogeographia delle Alpi sud-orientali. Udine.

Bachmann, M.; Bendix, J. 1993: Nebel im Alpenraum: eine Untersuchung mit Hilfe digitaler Wettersatellitendaten. Bonner Geographische Abhandlungen.

Barry, R.G. 1974: Topo and mikroclimatology in alpine areas. Arctic and alpine environments, str. 73-83, London.

Barry, R.G. 1981: Mountain Weather and Climate. London, New York. 
Bohinec, V. 1935: K morfologiji in glaciologiji Rateške pokrajine. Geografski vestnik 11, str. 100-132. Ljubljana.

Digitalni model reliefa Slovenije, 1992, Zavod R Slovenije za statistiko. Ljubljana.

Gabrovec, M.; Krevs, M. 1988-1991: SONČEK. Program za računanje osončenja in sončne energije.

Gams, I.; Lovrenčak, F.; Plut, D. 1978: Soča, Breginj in Kamno v pokrajinsko-ekološki primerjavi. Zbornik Zgornje Posočje, str. 335-347. Ljubljana.

Gams, I. 1987: Ecological Altitudinal Zoning and its Climatic Explanation (An Example of the Slovene Alps). Biogeographia, letnik 13 (1987), str. 291-303.

Gams, I. 1992: Prispevek k mladokvartarni geomorfologiji v Zgornjesavski dolini. Geografski zbornik 32 (1992), str. 5-49. Ljubljana.

Geiger, R. 1966: The Climate Near the Ground. Cambridge.

Klimatografija Slovenije, tretji zvezek, 1991: Sončno obsevanje 1961-1990. Hidrometeorološki zavod Slovenije. Ljubljana.

Lehmkuhl, F.; Boehner, J.; Tilman Trost, K. 1992: Die nivale Hoehenstufe und ein Versuch ihrer klimatischen Abgrenzung anhand ausgewaehlter Gebiete der Alpen und Skandinaviens. Erdkunde 46, št. 1, str. 3-13.

Lovrenčak, F. 1976: Zgornja gozdna meja v Kamniških Alpah v geografski luči ( primerjavi s Snežnikom). Geografski zbornik 16, str. 5-150. Ljubljana.

Lovrenčak, F. 1978: Zgornja gozdna meja Julijskih Alp v geografski luči. Inštitut za geografijo Univerze. Ljubljana.

Lovrenčak, F. 1983: The Timberline in the Yugoslav Alps. Geographica Iugoslavica 5, str. 31-35.

Lovrenčak, F. 1986: Zgornja gozdna meja v Julijskih Alpah in na visokih kraških planotah Slovenije. Geografski zbornik 26, str. 5-62. Ljubljana.

Lovrenčak, F. 1987: The upper forest line in the Julian Alps. Biogeographia 13, str. 113-118.

Melik, A. 1961: Vitranc, Zelenci in Bovško. Geografski zbornik 6, str. 287-331. Ljubljana.

Natek, K. 1983: Metoda izdelave in uporabnost splošne geomorfološke karte. Magistrska naloga. Univerza v Ljubljani, Filozofska fakulteta, Oddelek za geografijo. Ljubljana.

Plesnik, P. 1971: O vprašanju zgornje gozdne meje in vegetacijskih pasov v gorovjih JZ in SV Slovenije. Geografski vestnik 43, str. 3-24. Ljubljana.

Seibert, P. 1993: Der Foehn in den Alpen: ein aktueller Ueberblick. Geographische Rundschau 45, št. 2, str. 116-123.

Topografska karta 1:25.000, list Rateče, 1974.

Wetzel, K.F. 1994: Abflussbildung waehrend sommerlicher Niederschlaege in einen kleinen Einzugsgebiet der Noerdlichen Kalkalpen. Erdkunde 48, št. 3, str. 161-173. Winiger, M.; Bachmann, M.; Bendix, J. 1992: Nebel, Lufthaushalt und Lufthygiene im Alpenraum. Erdkunde 46, št. 3-4, str. 188-202. 


\section{SOME RESULTS OF CLIMATIC MEASUREMENTS PERFORMED IN PLANICA, WITH THE EMPHASIS ON THE MEASUREMENTS OF TERMINAL INCREMENTS OF TREES}

\section{Summary}

The insolation analysis of Planica valley has established that the insolation conditions are the most favourable in the lower part of the valley which lies at a lower altitude and is surrounded by a lower horizon; they are less favourable in the upper part where the bottom of the valley is surrounded by over $2000 \mathrm{~m}$ high mountain peaks. In wintertime, this part of the valley does not receive direct insolation at all, not even in the favourable meteorological conditions.

Due to the north-south direction of the valley, it is difficult to talk about its sunny or shady side. Yet, as regards the insolation, the western slope, under Ponce, has a better position. This is manifested by certain vegetation conditions (the occurrence of thermophil Sorbus aria) and, possibly, also longer lengths of terminal increments of laryx in particular. However, this can not be undisputably established because of great differences in the growth conditions of grounds of the sampling locations on the two slopes.

Different insolation of slopes during morning hours in favourable weather conditions causes air circulation which is typical of mountain valleys. The warmer air ascends up the insolated western slope under Ponce, while it descends down the shady eastern slope into the valley and along its course it continues towards the main valley. After the sun sets behind the horizon, relatively cold air from higher and colder crests begins to descend into the valley. The wind speed is low and, according to our measurements, it does not exceed $1.5 \mathrm{~m} / \mathrm{sec}$.

In the daytime, conditions are much more involved as regards local winds. To clarify the main characteristics, a greater number of measurements and observations would be necessary in proper weather conditions.

Measurements have shown, in accordance with our expectations, that in general, the higher the altitude is, the lower is the temparature. For the valley bottom calculations were done for early summer with cloudy weather and the temperature gradient of $-0.38 \mathrm{deg} \mathrm{C} / 100 \mathrm{~m}$ was established at minimum temperatures, and $-0.73 \mathrm{deg} \mathrm{C} / 100 \mathrm{~m}$ at maximum temperatures. In mostly clear weather, temperatures drop during the upper sun culmination at a rate of $0.79 \mathrm{deg} \mathrm{C} / 100 \mathrm{~m}$ on the west slope, and at a rate of $0.33 \mathrm{deg} \mathrm{C} / 100 \mathrm{~m}$ on the east slope.

Temperature gradients are roughly followed by the gradients of vertical increments of trees. Measurements performed in the first half of July 1994 showed the rate of 
vertical increment reduction at higher altitudes as follows: $3.6 \mathrm{~cm} / 100 \mathrm{~m}$ with beech, $3.3 \mathrm{~cm} / 100 \mathrm{~m}$ with laryx, $0.7 \mathrm{~cm} / 100 \mathrm{~m}$ with Pinus mugo, and $-2.7 \mathrm{~cm} / 100 \mathrm{~m}$ with spruce.

In a more detailed analysis of the results it can be noticed that the vertical increment can significantly differ from the one expected. Lesser or no dependence on the altitude is evident in the case of unfavourable growth conditions of ground (active or temporarily active aluvial fans, very steep slopes, snow avalanche tracks) and in the cases when sample trees were shaded by higher ones.

A certain "increment inversion" can occur in the case of stable growth conditions and thicker soil or lesser rockiness, and with laryx, also in better lighting conditions. 